Piotr Konieczny

Uniwersytet Warszawski

\title{
Działalność Iberoamerykańskiego Stowarzyszenia ds. Szkolnictwa Wyższego na Odległość (AIESAD) - zarys problematyki*
}

\author{
The activity of the Ibero-American Association for Higher \\ Distance Education (AIESAD) - selected issues
}

Streszczenie. Niniejszy artykuł prezentuje wybrane aspekty działalności Iberoamerykańskiego Stowarzyszenia ds. Szkolnictwa Wyższego na Odległość (AIESAD). Od ponad trzydziestu lat organizacja ta energicznie działa na rzecz rozwoju edukacji otwartej i kształcenia na odległość w regionie iberoamerykańskim. Wśród inicjatyw podejmowanych przez AIESAD na szczególną uwagę zasługują cyklicznie organizowane konferencje, działalność wydawnicza oraz realizacja wielostronnych projektów naukowych. W chwili obecnej stowarzyszenie to jest największą iberoamerykańską organizacją, której aktywność ukierunkowana jest na rozwój wspomnianego wcześniej modelu kształcenia.

Słowa kluczowe: AIESAD, kształcenie na odległość, szkolnictwo wyższe, Iberoameryka.

Summary. This article presents selected aspects of the Ibero-American Association for Higher Distance Education (AIESAD). For over thirty years, the organization has been vigorously working on the development of open and distance education in the Ibero-American region. Among the initiatives undertaken by AIESAD, periodically organized scientific conferences, publishing and the implementation of multilateral research projects deserve a particular attention. At the moment, this association is the largest within Ibero-American organizations whose activity is focused on the development of the aforementioned model of education.

Keywords: AIESAD, distance education, higher education, Ibero-America.

* Niniejszy tekst powstał w trakcie stażu badawczego realizowanego na Uniwersytecie Świętego Tomasza w Bogocie (Universidad Santo Tomás) w ramach programu Unii Europejskiej Erasmus Mundus Akcja 2. 


\section{Wprowadzenie}

W dniach 12-14 listopada 2014 roku odbyła się w Rio de Janeiro XVI Iberoamerykańska Konferencja ds. Szkolnictwa Wyższego na Odległość (Encuentro Iberoamericano de Educación Superior a Distancia). Tak jak w przypadku ubiegłych edycji, inicjatorem oraz patronem spotkania było Iberoamerykańskie Stowarzyszenie ds. Szkolnictwa Wyższego na Odległość (La Asociación Iberoamericana de Educación Superior a Distancia), zwane w skrócie AIESAD. Tegoroczna konferencja zorganizowana pod hasłem „Innowacje w kształceniu na odległość. Perspektywy dla Iberoameryki” zgromadziła wielu specjalistów w ww. dziedzinie, stanowiąc znakomitą okazję do wymiany doświadczeń oraz dyskusji nad przyszłością edukacji zdalnej w regionie.

Wydarzenie to klarownie wpisuje się w dotychczasową misję stowarzyszenia, które od ponad trzydziestu lat intensywnie działa na rzecz promocji i rozwoju kształcenia na odległość w obszarze iberoamerykańskiego szkolnictwa wyższego. Warto przyjrzeć się bliżej wybranym aspektom tejże aktywności. Zamysłowi temu będzie poświęcony niniejszy artykuł. Jednocześnie należy wyraźnie zaznaczyć, iż z uwagi na jego ograniczone ramy, zamiarem autora nie jest ukazanie całego spektrum zagadnień związanych z kształceniem na odległość w iberoamerykańskim szkolnictwie wyższym. Tematowi temu, wymagającemu głębszego potraktowania, poświęcone będzie odrębne opracowanie.

\section{Iberoamerykańskie Stowarzyszenie ds. Szkolnictwa Wyższe- go na Odległość (AIESAD) - geneza powstania}

Decyzję o utworzeniu stowarzyszenia AIESAD podjęto w trakcie obrad I Iberoamerykańskiego Sympozjum Rektorów Uniwersytetów Otwartych (I Simposio Iberoamericano de Rectores de Universidades Abiertas) zorganizowanego 5-10 października 1980 roku w Madrycie. Uznano wówczas za właściwe powołanie do życia instytucji, która ułatwiałaby przepływ informacji między zainteresowanymi uniwersytetami oraz podejmowała działania na rzecz rozwoju kształcenia na odległość w regionie (García Aretio, 1992, s. 28). Podczas spotkania została wyznaczona Komisja Organizacyjna, której misją stała się budowa fundamentów pod przyszłe stowarzyszenie. Instytucjami, którym przypadło owo zadanie, były: Universidad Nacional de Educación a Distancia (UNED) z Hiszpanii, Universidad Estatal a Distancia (UNED) z Kostaryki, Universidad Nacional Abierta (UNA) z We- 
nezueli, Universidad de la Sabana z Kolumbii, Universidad Nacional Autónoma de México oraz Universidade de Brasilia.

Zgodnie ze statutem stowarzyszenia cele AIESAD zostały ukierunkowane na szeroko rozumiany rozwój edukacji zdalnej w obszarze iberoamerykańskiego szkolnictwa wyższego. Władze organizacji starają się stwarzać swym członkom warunki do wspólnej współpracy oraz wymiany informacji na temat funkcjonowania, rozwoju oraz ewaluacji szkolnictwa wyższego na odległość. Duże znaczenie dla AIESAD ma promocja oraz wspieranie badań naukowych realizowanych przez stowarzyszone instytucje. Zdając sobie sprawę, jak ważne znaczenie we współczesnym kształceniu na odległość odgrywają nowe rozwiązania metodologiczne oraz techniczne, AIESAD zachęca i wspiera swych członków do ich racjonalnego wdrażania. Mobilność kadry akademickiej, pracowników administracyjnych oraz studentów to kolejny punkt, którego rozwojowi - zgodnie ze statutem - sprzyja stowarzyszenie. Ponadto, współpraca międzyinstytucjonalna winna zmierzać do tworzenia wspólnych kursów i materiałów dydaktycznych. Wszystkie powyższe cele mają prowadzić w sposób nieunikniony do ciągłej poprawy jakości szkolnictwa wyższego na odległość.

Członkami AIESAD mogą zostać: 1) uniwersytety (lub inne instytucje szkolnictwa wyższego) z regionu iberoamerykańskiego, opierające swą ofertę dydaktyczną na edukacji zdalnej oraz prowadzące badania naukowe nad ww. modelem kształcenia, 2) uniwersytety stacjonarne $\mathrm{z}$ regionu iberoamerykańskiego, które posiadają w swej ofercie kursy realizowane na odległość, 3) instytucje iberoamerykańskie lub międzynarodowe zainteresowane prowadzeniem badań nad ww. modelem kształcenia oraz wykorzystaniem ich rezultatów na rzecz iberoamerykańskiej edukacji.

Od początku swego istnienia AIESAD wiążą silne związki z Narodowym Uniwersytetem Kształcenia na Odległość (Universidad Nacional de Educación a Distancia - UNED). W madryckiej siedzibie uczelni po dziś dzień znajduje się Stały Sekretariat Iberoamerykańskiego Stowarzyszenia.

\section{Iberoamerykańskie Konferencje AIESAD}

AIESAD dokłada wielu starań, by pobudzać i rozwijać debatę naukową w zakresie edukacji zdalnej. Ich urzeczywistnieniem są m.in. wspomniane we wstępie Iberoamerykańskie Konferencje ds. Szkolnictwa Wyższego na Odległość, organizowane średnio co dwa lata w różnych miastach regionu (Miranda Justiniani, Yee Seuret, 2010, s. 22-25). 
Pierwsze tego typu spotkanie zorganizował w listopadzie 1984 roku, w Bogocie, Kolumbijski Instytut na rzecz Upowszechniania Szkolnictwa Wyższego (Instituto Colombiano para el Fomento de la Educación Superior - ICFES). Zarówno ta, jak i następna Konferencja (X 1986 roku, Tucumán/Argentyna) postawiły sobie za cel próbę umiejscowienia iberoamerykańskich doświadczeń w zakresie kształcenia na odległość w szerszym, międzynarodowym kontekście. Konferencję III, zwołaną w kwietniu 1989 roku w stolicy Kostaryki San José poświęcono środkom dydaktycznym wykorzystywanym w kształceniu na odległość, ich projektowaniu, wytwarzaniu oraz końcowej ewaluacji. Jej organizację wziął na swoje barki Państwowy Uniwersytet Kształcenia na Odległość w Kostaryce (Universidad Estatal a Distancia - UNED), jeden z pionierów edukacji zdalnej w latynoamerykańskim szkolnictwie wyższym. Ponad rok później, w listopadzie 1990 roku Narodowy Uniwersytet Otwarty z Wenezueli (Universidad Nacional Abierta UNA) zorganizował w Caracas IV Konferencję, czyniąc tematem jej obrad zależności między kształceniem na odległość a szeroko rozumianym rozwojem. Spotkanie to pokrywało się z organizowaną w tym kraju XV Światową Konferencją Międzynarodowej Rady Kształcenia na Odległość (International Council for Open and Distance Education - ICDE). Dwa lata później, w listopadzie 1992 roku, z okazji V Konferencji AIESAD regionalnych badaczy gościł w Madrycie Narodowy Uniwersytet Kształcenia na Odległość (Universidad Nacional de Educación a Distancia - UNED). Obrady zbiegły się z obchodami dwudziestej rocznicy powołania do życia tej niezwykle zasłużonej uczelni (Konieczny, 2012, s. 292-307). Jej doświadczenia stały się punktem odniesienia dla wielu instytucji, nie tylko iberoamerykańskich. W związku z faktem, iż to właśnie utworzenie hiszpańskiego UNED stało się impulsem do rozwoju ww. modelu w iberoamerykańskim szkolnictwie wyższym, rocznicowe spotkanie poświęcono wstępnej analizie doświadczeń w zakresie regionalnej współpracy na rzecz rozwoju szkolnictwa wyższego na odległość. Przedmiotem kolejnej konferencji - zorganizowanej w maju 1995 roku - uczyniono kształcenie specjalistów w ww. dziedzinie. Tym razem, uczestników debaty przyjął Narodowy Uniwersytet Autonomiczny Meksyku (Universidad Nacional Autónoma de México - UNAM). Dokładnie dwa lata później, w maju 1997 roku, przywilej organizowania VII Konferencji AIESAD przypadł brazylijskiemu Universidade Salgado de Oliveira. Po raz pierwszy - aczkolwiek nie ostatni - uczestników debaty gościło Rio de Janeiro, zaś obrady koncentrowały się wokół doświadczeń uniwersytetów kształcących na odległość w zakresie nauk humanistycznych, społecznych i prawnych. 
Wychodząc z założenia, iż jakość i skuteczność edukacji zdalnej w XXI wieku będzie nierozerwalnie związana $\mathrm{z}$ technologami informacyjno-komunikacyjnymi, tematykę tę uczyniono przedmiotem dyskusji w trakcie VIII Konferencji AIESAD, zwołanej w lipcu 1999 roku w ekwadorskim Quito. Organizatorem spotkania była stołeczna Politechnika Wojskowa (Escuela Politécnica del Ejército - ESPE). Dwa lata później, w lipcu 2001 roku przywilej zorganizowania IX Konferencji przypadł po raz drugi Kolumbii. Tym razem, uczestników spotkania gościła Cartagena de Indias, zaś trudu organizacyjnego podjął się Universidad Nacional Abierta y a Distancia. Przedmiotem dyskusji w trakcie zjazdu uczyniono przyszłość edukacji zdalnej w regionie. Dwie kolejne konferencje zorganizowały instytucje posiadające doświadczenie w tej materii. W lipcu 2003 roku uczestników debaty gościł w San José kostarykański UNED, zaś w czerwcu 2005 roku świadkiem naukowego spotkania była po raz kolejna siedziba meksykańskiego UNAM. Tematy wokół, których toczyła się dyskusja, brzmiały odpowiednio „Jakość, technologia a wartości w kształceniu na odległość” (X Konferencja) oraz „Umiędzynarodowienie szkolnictwa wyższego na odległość" (XI Konferencja). O tym, jak ważna w debacie nad zdalną edukacją jest sprawa jakości kształcenia, może również świadczyć temat kolejnej, XII Konferencji, zorganizowanej w czerwcu 2007 roku w dominikańskim Puerto Plata, przez stosunkowo niewielką jednostkę akademicką, jaką jest Uniwersytet Otwarty dla Dorosłych (Universidad Abierta para Adultos - UAPA). Przedmiotem debaty uczyniono jakość szkolnictwa wyższego na odległość w przestrzeni euro-latynoamerykańskiej.

We wrześniu 2009 roku obrady przeniosły się po raz kolejny na Półwysep Iberyjski. Uczestników spotkania gościł w Lizbonie portugalski Uniwersytet Otwarty (Universidade Aberta). XIII Konferencję poświęcono tematowi sieci uniwersyteckich na poziomie studiów magisterskich i doktoranckich (postgrados) oraz w kształceniu ustawicznym. Kolejna, XIV Konferencja została zorganizowana przez ekwadorski Universidad Técnica Particular de Loja we wrześniu 2011 roku. Z racji tego, iż rok wcześniej AIESAD świętował trzydziestolecie swej działalności, nie dziwi fakt, że obrady spotkania poświęcono podsumowaniu dotychczasowych osiągnięć oraz podkreśleniu wyzwań, jakie stoją przed iberoamerykańskimi uczelniami w zakresie rozwoju kształcenia na odległość. Przedostatnia, XV Konferencja miała miejsce 28-31 październiku 2012 roku w Cartagena de Indias. Uczestników debaty po raz kolejny gościł Universidad Nacional Abierta y a Distancia, kolumbijska uczelnia specjalizująca się w kształceniu na odległość. Spotkanie poświęcono roli edukacji zdalnej w budowie społeczeństw włączających. 
Powyższe zestawienie pokazuje wyraźnie, iż w organizacji Iberoamerykańskich Konferencji biorą udział instytucje z niemal całego regionu. Od 1984 roku zorganizowano łącznie szesnaście tego typu debat, trzy w Kolumbii, po dwie w Brazylii, Ekwadorze, Kostaryce i Meksyku, oraz po jednej w Argentynie, Hiszpanii, Portugalii, Republice Dominikańskiej i Wenezueli.

\section{Działalność wydawnicza AIESAD}

Dążąc do realizacji celów zapisanych w swym statucie, władze AIESAD uznały za właściwe powołanie do życia organu wydawniczego, ułatwiającego komunikację z wszystkimi członkami stowarzyszenia. Taki właśnie cel przyświecał publikacji „Biuletynu Informacyjnego” („Boletín Informativo de la Asociación Iberoamericana de Educación a Distancia" - BIESAD). W latach 1981-1987 ukazały się 22 numery pisma, na łamach którego zamieszczono łącznie 85 artykułów. Trzeba przy tym podkreślić, iż biuletyn ten nie miał charakteru naukowego (García Aretio, Ruiz Corbella, 2011, s. 21).

W 1988 roku „Boletín Informativo” został zastąpiony przez pismo „Revista Iberoamericana de Educación Superior a Distancia" (RIESAD), które takowy profil już posiadało. Do 1996 roku ukazały się 23 numery czasopisma, na którego łamach opublikowano łącznie 173 artykuły naukowe. W drugiej połowie lat dziewięćdziesiątych postanowiono poszerzyć jego zakres tematyczny. Poprzednio uwaga autorów koncentrowała się niemal wyłącznie na wykorzystaniu kształcenia na odległość w tytułowym szkolnictwie wyższym (educación superior). Z czasem uznano za właściwe ukierunkowanie badań na całość zagadnień związanych z iberoamerykańską edukacją zdalną. W związku z powyższym, od 1998 roku - do chwili obecnej - oficjalne czasopismo AIESAD ukazuje się pod tytułem „Revista Iberoamericana de Educación a Distancia” - RIED (García Aretio, Ruiz Corbella, 2011, s. 21).

Zarządzanie czasopismem leży w gestii Katedry UNESCO ds. Kształcenia na Odległość (Cátedra UNESCO de Educación a Distancia), działającej przy hiszpańskim UNED. Obowiązki administracyjne i techniczne związane z jego wydawaniem, promocją oraz dystrybucją spoczywają aktualnie na barkach ekwadorskiego Universidad Técnica Particular de Loja. Czasopismo ukazuje się raz na semestr, od 2006 roku publikowane jest zarówno w formie drukowanej, jak i elektronicznej. Na jego łamach zamieszczane są artykuły w języku hiszpańskim, portugalskim oraz angielskim. 


\section{Wybrane projekty AIESAD na rzecz współpracy międzynaro- dowej w regionie}

Ważnym aspektem działalności AIESAD jest realizacja przez jego członków wspólnych projektów zorientowanych na rozwój kształcenia na odległość w regionalnym szkolnictwie wyższym. Jak stwierdza Juan A. Gimeno Ullastres (2011, s. 7-8), duża część niniejszych inicjatyw koncentruje się na takich kwestiach, jak wypracowywanie norm i standardów jakościowych w kształceniu na odległość oraz wymiana akademicka w obrębie edukacji zdalnej. Warto przyjrzeć się bliżej wybranym przedsięwzięciom realizowanym pod auspicjami AIESAD (Gimeno Ullastres 2011, s. 7-9, Miranda Justiniani, Yee Seuret 2010, s. 25-29).

Troska o jakość edukacji znalazła swoje odbicie m.in. w realizacji przedsięwzięcia „Projekt Karaiby: Wirtualne Centrum na rzecz Rozwoju Standardów Jakościowych w Latynoamerykańskim Szkolnictwie Wyższym na Odległość” („Proyecto Caribe - Centro Virtual para el Desarrollo de Estándares de Calidad para la Educación Superior a Distancia en América Latina"). Celem powyższej inicjatywy było stworzenie silnych fundamentów pod budowę systemu normatywnego, który regulowałby jakość programów kształcenia w szkolnictwie wyższym na odległość. Dzięki temu, iż w projekcie uczestniczyło wiele instytucji, wypracowane rozwiązania udało się rozpowszechnić w licznych krajach regionu. Podobne cele przyświecały przedsięwzięciu „Projekt RUEDA: Ewaluacja programów kształcenia na odległość” („Proyecto RUEDA: Evaluación de Programas de Educación a Distancia"), realizowanemu przy wsparciu Unii Europejskiej. Opierając się na doświadczeniach uniwersytetów europejskich oraz latynoamerykańskich dążono do wypracowania takich rozwiązań metodologicznych, które przyczyniłyby się do polepszenia ewaluacji uniwersyteckich programów kształcenia na odległość.

Doświadczenia nabyte przy dwóch wcześniejszych przedsięwzięciach zaowocowały powołaniem do życia Instituto Latinoamericano y del Caribe de Calidad en Educación Superior a Distancia - CALED, dedykowanego sprawom jakości kształcenia na odległość w latynoamerykańskim szkolnictwie wyższym. Instytucja ta zachęca oraz wspiera regionalne uczelnie w zakresie ewaluacji programów kształcenia, współpracuje z krajowymi komisjami akredytacyjnymi, organizuje kursy wirtualne w ww. temacie oraz prowadzi intensywną działalność wydawniczą. Sekretariat Wykonawczy CALED znajduje się w siedzibie ekwadorskiego Universidad Técnica Particular de Loja.

Zasygnalizowana wcześniej współpraca z Unią Europejską ma również swoje odbicie w projektach skoncentrowanych na promocji mobilności aka- 
demickiej. W latach 2005-2007 w ramach programu ALFA wypracowano zasady, w ramach których dokonywała się wymiana studentów i doktorantów między poszczególnymi uczelniami europejskimi i latynoamerykańskimi. Podobny cel przyświecał projektowi „NetACTIVE: Credit Transfer in Virtual and Distance Education", realizowanemu w ramach programu Erasmus Mundus, przy współpracy z Europejskim Stowarzyszeniem Uniwersytetów Kształcących na Odległość (European Association of Distance Teaching Universities - EADTU).

W 2010 roku został zainicjowany projekt IBERVIRTUAL, realizowany pod auspicjami Szczytu Szefów Państw i Rządów Iberoamerykańskich. Głównym celem niniejszej inicjatywy są działania na rzecz edukacji włączającej w regionie, za sprawą kształcenia na odległość. W przedsięwzięciu uczestniczy 14 krajów, w których siedzibę mają uniwersytety wchodzące w skład AIESAD: Argentyna, Brazylia, Ekwador, Hiszpania, Kolumbia, Kostaryka, Kuba, Meksyk, Panama, Paragwaj, Peru, Portugalia, Republika Dominikańska, Wenezuela.

Warto podkreślić, iż od początku swego istnienia, stowarzyszenie aktywnie uczestniczy w formowaniu kadr nauczycielskich, wyspecjalizowanych w kształceniu na odległość. W 1983 roku, wspólnym wysiłkiem AIESAD i Hiszpańskiej Agencji ds. Współpracy Międzynarodowej (Agencia Española de Cooperación Internacional - AECI) zainicjowano organizację kursów dydaktycznych z zakresu zdalnego nauczania oraz edukacji dorosłych (Cursos Iberoamericanos de Educación a Distancia y Educación de Adultos). Zadania zaprojektowania oraz przeprowadzenia zajęć podjął się hiszpański UNED. O ile w przypadku pierwszych edycji szkolenie odbywało się w formie stacjonarnej, o tyle z czasem - dzięki możliwościom technicznym - zdecydowano, by w Madrycie realizować tylko część zajęć, zaś resztę w krajach pochodzenia poszczególnych uczestników. W 2013 roku hiszpańska uczelnia zorganizowała jubileuszową, XXX edycję kursu.

\section{Zakończenie}

W trakcie ponad trzydziestu lat swojej aktywności, stowarzyszenie AIESAD w istotny sposób przyczyniło się do rozwoju kształcenia na odległość w iberoamerykańskim szkolnictwie wyższym. Za sprawą podejmowanych inicjatyw organizacja ta stała się ważną płaszczyzną wymiany doświadczeń i kreowania nowych rozwiązań w obszarze edukacji zdalnej. Aspektem, który skupia szczególną uwagę AIESAD, jest troska o jakość oferowanego kształ- 
cenia na odległość. Nie dziwi więc fakt, iż z tematem tym wiążą się organizowane konferencje oraz specyfika realizowanych projektów międzynarodowych. W chwili obecnej omówione tu stowarzyszenie jest największą iberoamerykańską organizacją, działającą w obszarze edukacji otwartej i kształcenia na odległość. Tempo, w jakim rozwijają się we współczesnym świecie nowe technologie informacyjno-komunikacyjne, a także tendencje do ich wdrażania w obszar edukacji skłaniają do wniosku, iż podejmowane przez AIESAD inicjatywy będą zyskiwały na znaczeniu. Świadomość istnienia omówionego tu stowarzyszenia oraz wiedza na temat głównych aspektów jego działalności wydają się niezbędne do podjęcia refleksji i pogłębionych badań nad rozwojem edukacji zdalnej w krajach iberoamerykańskich.

\section{Bibliografia}

García Aretio L. (1992), Asociaciones y redes de Educación a Distancia, "Revista Iberoamericana de Educación Superior a Distancia”, nr 1, s. 19-31.

Konieczny P. (2012), Narodowy Uniwersytet Kształcenia na Odległość (UNED) w Hiszpanii - 40 lat w stużbie edukacji ustawicznej, „Rocznik Andragogiczny”, s. 292-307.

Miranda Justiniani A., Yee Seuret M. (2010), Educación a distancia en Iberoamérica: XXX aniversario de la AIESAD, "RIED. Revista Iberoamericana de Educación a Distancia”, nr 2, s. 13-36.

\section{Netografia}

García Aretio L., Ruiz Corbella M. (2011), Del Boletín Informativo de la Asociación Iberoamericana de Educación Superior a Distancia a la Revista Iberoamericana de Educación a Distancia (RIED): la aportación de AIESAD a la investigación sobre educación a distancia en América Latina, [w:] García Aretio L., Ruiz Corbella M. (red.), XXX Aniversario de la AIESAD. Asociación Iberoamericana de Educación Superior a Distancia (AIESAD), pionera en la divulgación científica sobre educación a distancia en Latinoamérica, AIESAD-UNED, Madryt, s. 11-34, dostępny na http://e-spacio.uned.es/fez/eserv.php?pid=bibliuned:UNESCO-libros-aniversarioAIESAD\&dsID=Documento.pdf (dostęp: 05.01.2015).

Gimeno Ullastres J.A. (2011), Prólogo, [w:] L. García Aretio, M. Ruiz Corbella (red.), XXX Aniversario de la AIESAD. Asociación Iberoamericana de Educación Superior a Distancia (AIESAD), pionera en la divulgación científica sobre educación a distancia en Latinoamérica, AIESAD-UNED, Madryt, s. 6-10, dostępny na http://62.204.192.148/libroaiesad/pdf/ inicio/aiesad_prologo.pdf (dostęp: 05.01.2015). 
